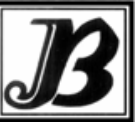

J. bio-sci. 19: 59-63, 2010

ISSN 1023-8654

http://www.banglajol.info/index.php/JBS/index

\title{
ASSESMENT OF THREE DIFFERENT PARAMETERS OF URBAN PONDS AT RAJSHAHI, BANGLADESH
}

\author{
FA Flowra*, JK Ghosh, AS Tumpa, SN Jahan \\ Department of Fisheries, University of Rajshahi, Rajshahi-6205, Bangladesh
}

\begin{abstract}
Context: Physico-chemical factors directly affect the water quality. Biological parameters varied from pond to pond according to the water quality.

Objective: To assess the physico-chemical conditions and plankton abundance in the studied ponds.

Materials and Methods: The study was carried out for a period of seven months from June, 2008 to December, 2008 in six ponds of Rajshahi Metropolitan area. Surface water samples were collected once a month at 10-11 am in black plastic bottle and analyzed for the estimation of different parameters. Water temperature, transparency, $\mathrm{pH}$, dissolved oxygen (DO), free carbon dioxide $\left(\mathrm{CO}_{2}\right)$, biological oxygen demand $(\mathrm{BOD})$, nitrite nitrogen $\left(\mathrm{NO}_{2}{ }^{-} \mathrm{N}\right)$, nitrite $\left(\mathrm{NO}_{2}\right)$, toxic ammonia, ammonium ion $\left(\mathrm{NH}_{4}{ }^{+}\right)$and total hardness were measured. The density of plankton was also estimated.

Results: The mean values of water temperature varied from $28.73 \pm 3.98$ (Pond 6) to $29.56 \pm 4.68^{\circ} \mathrm{C}$ (Pond 4) and the $\mathrm{pH}$ varied from $7.37 \pm 0.26$ (Pond 6) to $8.57 \pm 0.26$ (Pond 4). The DO varied $1.66 \pm 1.03$ (Pond 1) to $4.68 \pm 0.36$ $\mathrm{mg} / \mathrm{l}$ (Pond 6) and the mean value of free $\mathrm{CO}_{2}$ varied from $4.29 \pm 0.37$ (Pond 5) to $50.91 \pm 19.30 \mathrm{mg} / \mathrm{l}$ (Pond 3). The total hardness was $136.79 \pm 20.28$ (Pond 6) to $183.14 \pm 51.17 \mathrm{mg} / \mathrm{l}$ (Pond 3) with $\mathrm{NO}_{2}$-varied from $0.003 \pm 0.002$ (Pond 5) to $2.08 \pm 0.59 \mathrm{mg} / \mathrm{l}$ (Pond 4). The mean total phytoplankton was $28761.43 \pm 2912.62$ (Pond 2) to 63629.29 $\pm 20214.44 \mathrm{cells} / \mathrm{l}$ (Pond 4) and the mean total zooplankton was $13314.24 \pm 3189.70 \mathrm{cells} / \mathrm{l}$ (Pond 5) to $18820.00 \pm$ 932.51 cells/l (Pond 4).

Conclusion: The deterioration in the physico-chemical quality and plankton population observed in this study is alarming, and periodic monitoring and preventative measures are required to save the aquatic system from eutrophication.
\end{abstract}

Keywords: Physical parameter, chemical parameter, plankton concentration.

\section{Introduction}

The various water sources like ponds, lakes, rivers are used for industrial, domestic and agricultural purposes. These water bodies get polluted due to the discharge of effluents from the industries, domestic waste, land and agricultural drainages resulting in the degradation of water quality. Among the various means of pollutions of pond are washing of the clothes, cleaning of animals, dumping of the waste by unauthorized small scale units functioning in the surroundings to the pond. Haslam (1991) stated that due to the great expansion in the urbanization and industrialization, most of the water bodies especially in the developed countries are polluted.

The pond water is considered as one of the major sources for fishery and domestic uses. The consideration of the physico-chemical factors in the study of limnology is basic to the understanding of trophic dynamics of the water body. Each factor does play its individual role but at the same time the final effect is the actual result of the interaction of these factors. Planktons are sensitive to the environment in which they live, and any alteration in them leads to change in the plankton communities in terms of tolerance, abundance, diversity and dominance in the habitat. Phytoplanktons are the basic members in the aquatic ecosystems and hence change in phytoplankton population has a direct link with the change of water quality in any

*Corresponding author Email: flowrabd@yahoo.com 
aquatic medium (Dutta et al. 1954). Primary production of fish in water bodies depends upon their depth, type of land, chemical nature of the water body. Thus, better understanding of aquatic environments and productivity of aquatic communities are pre-requisite for improve utilization of these resources for human welfare. Therefore, present investigations have been made to find the different water quality parameters of some ponds of the Rajshahi Metropolitan area.

\section{Materials and Methods}

Study Ponds: The study was carried out for a period of seven months from June, 2008 to December, 2008 in six ponds of Rajshahi Metropolitan area. Surface water samples were collected once a month at 10-11 am in black plastic bottle and analyzed for the estimation of different parameters.

Physico-chemical parameters: Physico-chemical parameters were measured and recorded monthly basis thruoughout the study period. Surface water temperature was measured by dipping a Celsius thermometer. Transparency was measured by a secchi disc. pH was measured using a HACH kit, model FF-2, Cat. No. 2430-01, Made in USA. Wide range $4 \mathrm{pH}$ indicator solution was used. Dissolved oxygen (DO) and Biological Oxygen Demand (BOD) were measured by Winkler's Titration method (APHA 1976). Free $\mathrm{CO}_{2}$ was measured by titration method (Welch 1948). The total hardness was measured by the titration of ammonia buffer solution and resultant data was expressed according to Mishra and Saksena (1992). Nitrite nitrogen $\left(\mathrm{NO}_{2}{ }^{-} \mathrm{N}\right)$, nitrite $\left(\mathrm{NO}_{2}\right)$, toxic amonia and ammonium ion were measured by $\mathrm{HACH}$ kit, model FF2, USA.

Biological Parameters: Among biological parameters only phytoplanktons and zooplanktons were studies. Qualitative study of plankton was done accordingly to Anagnostidis and Komarek (1985), Skulberg et al. (1993), Bellinger (1992), Khondker (1997). The density of plankton was estimated by using a SedgewickRafter (S-R) cell. Calculation of plankton samples were accomplished by the method of Stirling (1985).

\section{Results}

Physico-chemical Parameters: Different estimated values of the water qualities varied from pond to pond, and the calculated data are presented in the Table 1. The mean values of water temperature varied from $28.73 \pm 3.98{ }^{\circ} \mathrm{C}$ (Pond 6) to $29.56 \pm 4.68^{\circ} \mathrm{C}$ (Pond 4). Water transparency was $26.46 \pm 5.13$ (Pond 4) to $41.35 \pm 10.88 \mathrm{~cm}$ (Pond 1 ) and the average $\mathrm{pH}$ in the present study was found to vary from $7.37 \pm 0.26$ (Pond 6) to $8.57 \pm 0.26$ (Pond 4). DO varied from $1.66 \pm 1.03 \mathrm{mg} / \mathrm{l}$ (Pond 1) to $4.68 \pm 0.36 \mathrm{mg} / \mathrm{l}$ (Pond 6) whereas free $\mathrm{CO}_{2}$ varied from $4.29 \pm 0.37 \mathrm{mg} / \mathrm{l}$ (Pond 5 ) to $50.91 \pm 19.30 \mathrm{mg} / \mathrm{l}$ (Pond 3). The average BOD varied from $1.34 \pm 0.66 \mathrm{mg}^{-1}$ (Pond 4) to $2.53 \pm 0.48 \mathrm{mg} / \mathrm{l}$ (Pond 6). The mean total hardness was $136.79 \pm 20.28 \mathrm{mg}^{-1}$ (Pond 6) to $183.14 \pm 51.17 \mathrm{mg} / \mathrm{l}$ (Pond 3). The concentration of $\mathrm{NO}_{2}-\mathrm{N}$ varied form $0.06 \pm 0.04 \mathrm{mg}^{-1}$ (Pond 5) to $0.63 \pm 0.18 \mathrm{mg} / \mathrm{l}$ (Pond 4). $\mathrm{NO}_{2}$ - varied from $0.003 \pm 0.002$ (Pond 5) to $2.08 \pm 0.59 \mathrm{mg} / \mathrm{l}$ (Pond 4) and the toxic ammonia ranged from $0.0007 \pm 0.0005$ (Pond 6) to $0.27 \pm 0.02 \mathrm{mg} / \mathrm{l}$ (Pond 1).

Biological Parameters: Chlorophyceae was found to be the most dominant group followed by Euglenophyceae, Myxophyceae, Bacillariophyceae and Cyanophyceae (Table 1). Among the zooplanktons Cladocera was found to be the most dominant group followed by Rotifera, Copepoda and Nauplius. The variations in the mean values of plankton under different pond are shown in Table 1. A total of five groups of phytoplanktons and four groups of zooplanktons were identified during the study. The mean value of total phytoplankton varied from $28761 \pm 2913$ (Pond 2) to $63629 \pm 20214$ cells/l (Pond 4) (Table 1) and zooplankton varied from $13314 \pm 3190 \mathrm{cells} / \mathrm{l}$ (Pond 5) to $18820 \pm 932 \mathrm{cells} / \mathrm{l}$ (Pond 4) (Table 1)

\section{Discussion}

Boyd (1982) suggested the suitable temperature for fish culture is $26.06-31.97^{\circ} \mathrm{C}$. Sweeting (1994) mentioned that water temperature changes due to the discharge of effluents and may also cause physical pollution in the water bodies. Trivedi and Raj (1992) found thermal pollution can affect fish culture. A 
transparency value in between 15 to $40 \mathrm{~cm}$ is found good for fish culture (Boyd 1982). According to Chhatwal et al. (1989), pH of natural water remains nearly 7 but generally high due to the presence of sufficient quantities of carbonate and bicarbonate. Generally free $\mathrm{CO}_{2}$ was found lower than the dissolved oxygen contents. It appears that low concentrations of free $\mathrm{CO}_{2}$ in samples of pond- 4 and 5 , due to its utilization by aquatic plants (rooted emergent and floating hydrophytes) during the process of photosynthesis. However, at pond-1, 2 and 3, it fluctuated frequently higher than dissolved oxygen. Among all the ponds studied, lowest oxygen concentrations was recorded in the samples of Pond-1 (Hadirmore) due to excess use of pond water for washing cloths and household utensils.

Table 1. Mean variation of physical and chemical factors in different ponds

\begin{tabular}{|c|c|c|c|c|c|c|}
\hline Parameters & Pond-1 & Pond-2 & Pond-3 & Pond-4 & Pond-5 & Pond-6 \\
\hline${ }^{\circ} \mathrm{C}$ & 29.37 & $29.08=$ & 29.27 & $29.56 \pm 4.68$ & $29.19 \pm 3.39$ & $28.73 \pm 3.89$ \\
\hline Tran & 10.88 & 29.3 & 28. & 3 & 29.6 & 73 \\
\hline $\mathrm{pH}$ & $8.16 \pm 0.42$ & $8.09 \pm 1.07$ & $8.41 \pm 0.31$ & $8.57 \pm 0.26$ & $7.53 \pm 0.39$ & $7.37 \pm 0.26$ \\
\hline $\mathrm{DO}(\mathrm{mg} / \mathrm{l})$ & $1.66 \pm$ & $2.85 \pm$ & $1.68 \pm$ & $1.93 \pm 0.23$ & 4.49 & $4.68 \pm 0.36$ \\
\hline Free $\mathrm{CO}_{2}(\mathrm{mg} / \mathrm{l}$ & $42.60 \pm$ & $34.09 \pm 7.71$ & $50.91=$ & 59.49 & $4.29=$ & $4.37 \pm 0.84$ \\
\hline BOD (mg/l) & $1.60 \pm 0.99$ & $2.34 \pm 1.15$ & $1.68 \pm 0.72$ & $1.34 \pm 0.66$ & $2.48 \pm 0.50$ & $2.53 \pm 0.48$ \\
\hline $\begin{array}{l}\text { Hardness } \\
\mathrm{NO}_{2}^{-2}-\mathrm{N}\end{array}$ & $\begin{array}{l}154.43 \\
0.34 \pm 0\end{array}$ & $\begin{array}{l}142.71 \\
0.16 \pm 0\end{array}$ & $\begin{array}{l}183.14 \\
0.33 \pm\end{array}$ & $\begin{array}{l}159.04 \\
0.63 \pm\end{array}$ & $\begin{array}{l}140.59 \\
0.06 \pm\end{array}$ & $\begin{array}{l}136.70 \\
0.17 \pm\end{array}$ \\
\hline $\mathrm{NO}_{2}{ }^{-}($ & 1.11 & $0.53 \pm$ & 1.08 & $2.08 \pm$ & .0003 & .003 \\
\hline Toxic $\mathrm{NH}_{3}(\mathrm{mg} / \mathrm{l})$ & $0.27 \pm 0.02$ & $0.006 \pm 0.004$ & $0.05 \pm 0.23$ & $0.05 \pm 0.03$ & $0.0009 \pm 0.0007$ & $0.0007 \pm 0.0005$ \\
\hline $\mathrm{NH}_{4}^{+}(\mathrm{mg} / \mathrm{l})$ & $1.38 \pm 0.42$ & $0.29 \pm 0.10$ & $0.31 \pm$ & $0.15 \pm$ & 0.0002 & $0.0004 \pm 0.0001$ \\
\hline eae & 4598.57 & $4160.14 \pm$ & $4546.57=$ & $5111.71 \pm$ & $5121.43=$ & 121.17 \\
\hline Bacillariophyceae & $1943.29 \pm 436.26$ & $2044.86 \pm 442.10$ & $2052.86 \pm 103.93$ & $1413.71 \pm 248.33$ & $3764.43 \pm 1595.36$ & $3265.57 \pm 1221.07$ \\
\hline Cyan & $2202.43 \pm 1023.19$ & $2041.14 \pm 733.03$ & $3970.71 \pm 438.85$ & $4210.71 \pm 2801.68$ & $4625.14 \pm 1269.97$ & 69.78 \\
\hline Mixo & $1922.00 \pm 1123.87$ & $2151.71 \pm 930.49$ & $2222.00 \pm 1080.00$ & $288.29 \pm 206.45$ & $5078.43 \pm 1882.67$ & $5300.14 \pm 1392.74$ \\
\hline Cholorophyceae & $18915.29 \pm 1044.83$ & $18363.57 \pm 967.58$ & $19860.43 \pm 860.56$ & $14707.86 \pm 6891.10$ & $15219.57 \pm 2088.39$ & $15631.14 \pm 3493.40$ \\
\hline Total & $29581.57 \pm 3048.18$ & 28761.4 & 32652.57 & 63629.29 & 33809.00 & $34123.71 \pm 5668.97$ \\
\hline Cladocera & $5313.86 \pm 946.22$ & $5168.29 \pm 1041.40$ & $4832.14 \pm 838.24$ & $6292.57 \pm 576.62$ & $3826.43 \pm 1379.31$ & $3972.71 \pm 1446.92$ \\
\hline Rotifera & $4892.43 \pm 644.13$ & $4838.86 \pm 167.89$ & $5647.86 \pm 401.94$ & $5482.14 \pm 300.69$ & $4924.71 \pm 1074.65$ & $5113.71 \pm 1469.11$ \\
\hline Copepoda & $4533.29 \pm 700.64$ & $4405.43 \pm 501.74$ & $4537.43 \pm 528.54$ & $4262.43 \pm 485.58$ & $3037.00 \pm 675.69$ & $3165.86 \pm 626.90$ \\
\hline Nauplius & $3143.71 \pm 854.77$ & $2644.00 \pm 403.67$ & $2673.57 \pm 198.75$ & $2782.86 \pm 370.39$ & $1526.14 \pm 75797$ & $1115.14 \pm 625.10$ \\
\hline |s/l) & & $1705657+1714$ & .13 & 1 & 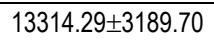 & 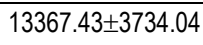 \\
\hline
\end{tabular}

Sreenivasan (1964) has argued that high level of free $\mathrm{CO}_{2}$ in comparison with oxygen indicates high level of decomposition for organic matter in a water body rather than its production. Naz (1999) noticed that the highest value of $B O D$ in summer to early monsoon may be attributed due to the maximum biological activity at elevated temperature, whereas the lower BOD values indicates lower biological activity. Higher value of BOD indicates very high degree of organic pollution (Rao 1979). The range of total hardness in the study indicates that the water of these ponds between soft to hard condition according to the range of hardness described by McCutcheon et al. (1992). High values of total hardness in the samples perhaps occurred due to the surface runoff. The concentration of $\mathrm{NO}_{2}-\mathrm{N}$ in the present study varied form $0.06 \pm 0.04 \mathrm{mg}^{-1}$ (Pond 5) to $0.63 \pm 0.18 \mathrm{mg} / \mathrm{l}$ (Pond 4). This range varied due to enrichment through drainage of decomposed material, 
surface run of from outside of the ponds. Water bodies subjected to organic pollution consist of high concentration of $\mathrm{NO}_{2}-\mathrm{N}$ (Khondkar, 2000). Popma (2005) reported that prolonged exposure (several weeks) of Tilapia to unionized ammonia concentration greater than $1 \mathrm{mg} / \mathrm{l}$ caused losses, especially among fry and juveniles in Iwater with low DO concentration. In the study $\mathrm{NH}_{4}{ }^{+}$ranged from $0.0004 \pm 0.0001$ (Pond 6) to $1.38 \pm 0.42 \mathrm{mg} / \mathrm{l}$ (Pond 1).

Total concentration of phytoplankton in the present study is more or less similar with Hossain et al. (2007) who found the value ranged from 60880 to 239400 units/l in fishpond of Bangladesh. This variation is due to the effect of seasonal abundance and similar results was observed by Rahman et al. (1999) and Hossain and Bhuiyan (2007). In the present study the mean concentration of cladocera was highest followed by rotifera, copepoda and nauplius larvae respectively. This findings agreed with Choudhury and Mamun (2006) and Bhuiyan et al. (2008).

\section{Conclusion}

The present investigations accomplished that phytoplankton and zooplankton are showing direct relationship with favourable conditions of alkalinity, maximum DO, minimum BOD which develop most favourable environment of fish production in the study ponds. It is clear from the results that the pond is mesotrophic and aging towards eutrophication. Hence measures should be taken to minimize the fresh water pollution by preventing washing of clothes and other bad practices of human.

\section{Acknowledgement}

The authors are very much grateful to Dr Sabrina Naz, Professor, Department of Botany and Dr Md Redwanur Rahman, Assistant Professor, Institute of Environmental Science, University of Rajshahi, for their encouragement and laboratory support. Also special thanks and gratitude to Md Aminul Islam, Scientific Officer, Soil Resource Development Institute (SRDI), Rajshahi

\section{References}

Anagnostidis K, Komarek, J. 1985. Modern approach to the classification system of Cyanophytes. 1-Introductionn. Arch Hydrobiol (Supl71) 38/39, 291-302.

APHA. 1976. Standard methods for the examination of water and waste water (14th ed.). American Public Health Association, Washington. 1193pp.

Bellinger EG. 1992. A key to common Algae: freshwater, estuarine and coastal species. The Institute of Water and Environmental Management, London, UK. 138pp.

Bhuiyan AS, Islam SN, Bhuiyan SS. 2008. Seasonal occurrence of some copepods in relation to the physico-chemical conditions of a fish pond in Rajshahi, Bangladesh. Fishing Chimes India 28(4), 39-41.

Boyd CE. 1982. Water quality management for pond fish culture. Elsevier Science Publishers B.V., 1000 AH Amsterdam, Netherlands. $318 \mathrm{pp}$.

Chhatwal GR, Mehra MC, Satake M, Katyal T, Katyal M, Nagahiro T. 1989. Encyclopedia of Environmental pollution and Its Control. Anmol Pbulication, New Delhi. 6, 204.

Chowdhury A, Mamun AA. 2006. Physiochemical conditions and plankton population of two ponds in Khulna. Univ J Zool Rajshahi Univ 25, $41-44$.

Dutta N, Malhotra JC, Bose BB. 1954. Hydrobiology and Seasonal fluctuations of the phytoplankton in the Hooghly estuary. Symp Marine and Freshw. Plankton in the Indo-pacific Bangkok. 35-47.

Haslam SM. 1991. River pollution and ecological perspective. CBS Publishers and Distributors, Delhi, India. 253pp.

Hossain MA, Bhuiyan AS. 2007. Study of water quality in fish ponds under the red soil zone of northern Bangladesh. J Subtrop Agric $\operatorname{Dev} 5(5), 347-351$. 
Hossain MY, Jasmine S, Ibrahim MHA, Begum M, Mamun A, Wahab MA. 2007. A preliminary observation on water quality and plankton of an earthen fishpond in Bangladesh. Pak J Biol Sci 10(6), 868-873. http://dx.doi.org/10.3923/pjbs.2007.868.873 PMid:19069880

Khondker M. 1997. Baboharic Limnology O Mithapanir Jalaja Udvider Parichiti. Published by Dhaka University, Dhaka, Bangladesh. 81$183 p p$.

Khondker M. 2000. Limnology. Dhaka University Publishing Association, Dhaka University of Dhaka. 151-164.

McCutcheon SC, Martin JL, Barnwell Jr. TO. 1992. Water quality. In: Maidment DR (ed.) Handbook of Hydrology. McGraw-Hill Book Co. Inc., pp. 11.1-11.73.

Mishra SR, Saksena DN. 1992. Aquatic Ecology. Asish Pub. House, 8/81 Pungabibugh, Delhi. 333 pp.

Naz S. 1999. Studies on the limnological characteristics and tropic status of four Pisciculture ponds in Rajshahi. Ph.D. thesis, Department of Botany, Rajshahi University, Bangaldesh. 278pp.

Popma T. 2005. Tilapia: Life History and Biology. Auburn University and Michael Masser, Texas A \& M University and published by the Southern Regional Agricultural Center and the Texas Aquaculture Extension Service. 7-25.

Rahman MS, Shaha DK, Rashid MH, Hasan MR. 1999. Effect of fertilization on the production of Indian Major carps. Bangladesh J Aquac 21, 47-52.

Rao SVR. 1979 Impact of pollutants of the primary production of the flora of river Khan. Ph.D. Thesis, School of Studies in Botany. Vikram University, Ujjain. $310 \mathrm{pp}$.

Skullberg OM, Carmichael WW, Codd GA, Skulberg R. 1993. Taxonomy of toxic Cyanophyceae (Cyanobacteria). In: Algal Toxins in Seafood and Drinking Water. (ed. I. R. Falcnor), Academic Press Ltd., London. 145-164.

Sreenivasan A. 1964. Hydrobiological study of a tropical impondments Bhavanisagar reservoir, Madras State, India for the year 195661. Hydrobilogia 24(4), 514-539. http://dx.doi.org/10.1007/BF00142000

Stirling HP. 1985. Chemical and Biological methods of water analysis for Aquaculturists. Institute of Aquaculture, University of Stirling, Scotland. 119pp.

Sweeting RA. 1994. River Pollution. In: Calow, P. and Petts, G. E. (Eds.) The Rivers Handbook. Hydrobiological and Ecological Principles. Oxford, Blackwell Scientific Publ., London. 23-32.

Trivedi PR, Raj G. 1992. Water pollution. Akashdeep Publishing House, New Delhi. 304pp.

Welch PS. 1948. Limnology. McGraw-Hill Book Company Inc. New York. 218p. 